\title{
Long Term Cultivation Effect on Soil Health Inside Poly Houses Under Sub-Tropical Condition of North East India
}

\author{
Kaberi Mahanta $^{1 *}$, R. Yendrembam ${ }^{1}$, D. Nath $^{1}$, A. Baishya ${ }^{1,}$ M. C. Talukder ${ }^{1}$, \\ A. K. Sarma ${ }^{2}$ and D. J. Rajkhowa ${ }^{2}$ \\ ${ }^{1}$ Assam Agricultural University, Jorhat 785 013, Assam, India \\ ${ }^{2}$ Division of Natural Resource Management, ICAR Research Complex for NEH Region, \\ Umiam 793103, Meghalaya, India \\ *Corresponding author
}

\section{A B S T R A C T}

\section{Keywords}

Poly house, age groups, soil health, enzymatic activity, soil deteorioration

Article Info

Accepted:

12 February 2020

Available Online:

10 March 2020
Protected farming is becoming increasingly popular in different developed and developing countries of the world due to its multifaceted advantages. Study was carried out to evaluate the long term cultivation effect on soil health under poly houses of varying age groups. It was observed that after 3-5 years of cultivation, the soils under the poly houses were deteriorated due to formation of soil acidity, nutrient imbalance and reduction in microbial diversity and enzyme activity. Key soil enzymes, microbial biomass carbon and microbial population were assessed to understand the effect of poly house cultivation on soil health. $\mathrm{pH}$, organic carbon content and bulk density of poly house soil of varying age groups varied significantly with respect to open field soil. Significantly lower cation exchange capacity and total exchangeable bases were recorded in poly house of $>10$ years age irrespective of soil depth and seasons. The available $\mathrm{N}, \mathrm{P}_{2} \mathrm{O}_{5}, \mathrm{~K}_{2} \mathrm{O}$ in soils showed an increasing trend up to 3-5 years of poly house age, thereafter decreased significantly. Irrespective of seasons and soil depth, the bacterial and fungal population showed a decreasing trend with advancement of poly house age. The microbial biomass carbon, dehydrogenase activity, phosphomonoesterase activity and Flourescent di acetate hydrolysis activity in soils showed a declining trend with increasing poly house age. Study indicated that the soils under poly houses required rejuvenation particularly after 6-8 years for improvement of physical, chemical and biological properties so as sustain soil health as well as crop productivity.

\section{Introduction}

Protected cultivation is gaining popularity across the world due to its multifaceted advantages like higher productivity and profitability, wider window of sowing or planting times, climate smart, safe and quality produce and enhanced resource use efficiency. Cultivation of many high value crops including horticultural crops, vegetables etc. in off season are economically profitable for producers. Crops grown under the poly houses are safer because of less damage by chemical residue, mechanical damage and are 
'of higher qualities (Chang and Liao, 1989). Besides these, cultivation in poly house protects crops from rain, hailstorm, snow and wind, improves seed bed condition, better seed germination, higher yield and quality (Antill, 1988).

Long term cultivation in poly house leads to deterioration of soil physical, chemical and biological properties which leads to the reduction in crop productivity. Micro environment such as temperature, moisture, aeration inside poly house together with tillage and fertilization cause the soil compaction, acidification, nutrient accumulation and imbalance in the soil ( $\mathrm{Li}$ et al., 1996).

Continuous poly house cultivation and management can cause reduction in the species diversity of the soil biota and may markedly change the microbial biomass, dehydrogenase activity and basal respiration was (Lee et al., 2004).

Further, low light intensity inside the poly house is known to increase various soils borne pathogens. Increased temperature under polyhouse $\left(2-3^{0} \mathrm{C}\right.$ in summer and $4-5^{\circ} \mathrm{C}$ in winter) leads to substantial reduction of organic matter emphasizing the need for use of organic manures and crop residues for maximizing profitability and maintaining environment quality (Sen et. al., 1984).

Further in winter, all sides of poly house are covered to keep the temperature high inside restricting the free flow of air that might reduce the activity of beneficial organisms. All these conditions affect the soil quality directly and indirectly affect the crops grown under the poly house.

In cognizance with the above, the present study was undertaken to evaluate the long term cultivation effect inside poly house of different age group on physico- chemical and biological properties of soil.

\section{Materials and Methods}

The present study was conducted in the Horticultural Research Farm of Assam Agricultural University, Jorhat, Assam, during 2013. The farm is located between $26^{\circ} 44^{\prime} \mathrm{N}$ latitude and $94^{\circ} 12^{\prime}$ longitude, at an elevation of $91.0 \mathrm{~m}$ above mean sea level. The climate of the area is humid subtropical characterized by hot and wet summer and dry and cool winter.

The data on the mean maximum and minimum temperature, relative humidity at morning and evening, total rainfall and sunshine hours inside the poly houses are presented in Fig.1. The experiment was laid out in Completely Randomized Design with 5treatments and 4 replications. The vegetable crops were cultivated inside the poly houses round the year. Poly houses of 4 age groups (0-2 yrs., 3-5 yrs., 6-8yrs. and >10yrs.) and four numbers of poly houses of each age group were selected as treatments and replications respectively. Non-poly house soils were taken as control from adjacent open areas of poly houses. Soil samples were collected from five different spots from each of the poly houses at two depths $(0-15 \mathrm{~cm}$ and $15-30 \mathrm{~cm})$ in winter and summer seasons.

\section{Soil physico-chemical characteristics}

The physico-chemical properties of soil was determined by following standard protocols i.e. clod method for bulk density (Blake, 1986), international pipette method for soil texture (Piper, 1966), Glass-electrode $\mathrm{pH}$ meter method for soil reaction (1: 2.5) (Jackson, 1973), Walkley and Black method for organic carbon (Jackson, 1973), centrifuge method for cation exchange capacity (Jackson, 1973), Alkaline permanganate 
method for available N (Subbiah and Asija, 1956), Bray's method for available $P$ (Jackson, 1973), flame photometric method for available K (Jackson, 1973).

\section{Soil biological characteristics}

\section{Soil microbial population}

The classical serial dilution technique was used for enumeration of microbial population (bacterial and fungal) by spread plate technique on nutrient agar media and rose bengal agar media, respectively. Rhizosphere soil sample of $1 \mathrm{~g}$ was suspended in $9 \mathrm{ml}$ water blank, followed by serially diluted up to $10^{3}, 10^{4}$ and $10^{4}, 10^{5}$ fungi and bacteria respectively . Aliquots of $100 \mu 1$ of $10^{3}, 10^{4}$ and $10^{4}, 10^{5}$ dilutions were spread over the solidified media in triplicates and plates were incubated at $30 \pm 2^{\circ} \mathrm{C}$ for $2-5$ days. The microbial numbers were estimated as colony forming unit (CFU) per gram soil on dry weight basis.

\section{Enzyme activities}

FDA hydrolysis activities were carried out following the method described by Adam and Duncan (2001). Soil was incubated with the substrate, FDA, at $25^{\circ} \mathrm{C}$ for 1 hour. The amount of fluoresce formed was determined colorimetrically (Nano Drop 1000 spectrophotometer) following extraction with an organic solvent mixture (2:1chloroform: methanol). Using the calibration curve the mass of fluoresce in produced in each assay from the corresponding optical density (OD at $490 \mathrm{~nm}$ ) value was calculated on dry weight basis. Fluorescent diacetate hydrolysis activity was expressed as $\mu \mathrm{g}$ fluorescent per gram dry soil per hour.

Dehydrogenase activities were determined by the reduction of triphenyl tetrazolium chloride (TTC) to triphenyl formazan (TPF) as described by Casida et al., (1968). Fresh soil (1g) treated with $1 \mathrm{ml}$ of $3 \% \mathrm{TTC}$, and then incubated at $28{ }^{\circ} \mathrm{C}$ for 24 hours. To account for any abiotic TTC reductions, sterile controls consisted of autoclaved soil $\left(121^{\circ} \mathrm{C}\right.$, 20 minutes. on three consecutive days) were used. Spectrophotometer blanks for both autoclaved and non-autoclaved treatments consisted of soil and TTC replaced with millipore water. Controls and blanks treated like samples. The optical density at $485 \mathrm{~nm}$ was compared to that of triphenyl formazan standards. Dehydrogenase activity was expressed on dry weight as $\mu \mathrm{g}$ TPF per gram dry soil per 24hours.

Phosphomonoesterase activities involve the use of an artificial substrate, $p$-nitrophenyl phosphate ( $p$-NPP).The product of Phosphomonoesterase activity, $p$-nitrophenol, a chromophore under alkaline conditions were detected colorimetrically following the method of Tabatabai and Bremner (1969) and expressed as $\mu g p$-nitrophenol per gram dry soil per hour.

\section{Microbial biomass carbon}

Soil microbial biomass carbon was determined by chloroform fumigation extraction technique following the method of Vance et al., (1987). Fresh soil (25 g) fumigated with ethanol free chloroform at 25 ${ }^{\circ} \mathrm{C}$ for 24 hours. After fumigation, chloroform vapours were removed by repeated evacuation. The soil samples were then extracted with $100 \mathrm{ml} 0.5 \mathrm{M} \mathrm{K}_{2} \mathrm{SO}_{4}$ (1:4 soil $\mathrm{K}_{2} \mathrm{SO}_{4}$ ). Controls were prepared by extracting soils without fumigation. The soil suspension was filtered through Whatman No 42 filter paper. Total organic carbon content in the soil extract was estimated with dichromate $(66.7 \mathrm{mM})$ digestion method (Walkley and Black, 1934). Microbial biomass carbon was calculated from the differences in extractable organic carbon between the fumigated and 
non-fumigated soil and expressed as $\mu \mathrm{g}$ per gram dry soil.

The analysis of data obtained was carried out following the statistical method of Completely Randomized Block Design (Panse and Sukhatme, 1967) for statistical significance the difference between the treatment means was tested with appropriate critical difference value at $1 \%$ and $5 \%$ level of probability. Simple correlation coefficient between soil physico-chemical properties and enzymatic activities were analyzed to establish possible statistical relationship (Chandel, 2004).

\section{Results and Discussion}

\section{Physico-chemical characteristics}

The significant variation in soil bulk density was recorded inside the poly houses compared to open field condition. Among the different age of the poly houses, highest bulk density was observed in $>10$ years age group followed by 6-8 years, 3-5 years and 0-2 years in both surface $(0-15 \mathrm{~cm})$ and sub-surface soil (15-30 cm) irrespective of seasons (Fig. 2.1 and 2.2). However, soil bulk density was higher in winter compared to summer in both surface and sub-surface soil. The result is in accordance with that of Patil and Bhagat (2014).

Soils $\mathrm{pH}$ ranged from 4.30-5.18 inside the poly houses and in open field irrespective of the season. However the $\mathrm{pH}$ of the open field was lower than the poly house soil. Among the different age group, highest soil $\mathrm{pH}$ was recorded in 3-5 years age group and lowest was recorded in $>10$ years age group (Table 1). Contribution of relatively higher soil $\mathrm{pH}$ in middle age group poly houses might be due to the application of fertilizer and organic manures resulting in increased the retention of exchangeable bases and the cation exchange capacity of the soil (Yaduvanshi et al., 1985). Decreased $\mathrm{pH}$ in soils of higher age poly houses might be due to excessive cultivation and irrigation that reduced the soil $\mathrm{pH}$.

Cation exchange capacity (CEC) of soils under poly houses and open field condition was mainly influenced by organic matter and clay content of the soil (Table 1). Result revealed higher CEC in surface soils as compared to sub surface soils. Similarly, CEC was higher during summer season compared to winter season. A higher CEC in summer season soils over winter season soils might be due to the faster decomposition of organic matter in summer season resulting in more addition of organic sources to the soil (Norman et. al.,2000). Further, the result revealed that the $>10$ years age group poly houses showed lower CEC, due to loss of soil organic carbon by continuous cropping and application of fertilizer. This result is in accordance with the result of Basumatary (1995), who also reported a decline in CEC and base saturation of soil after 7 years of continuous cropping under chemical amendments.

The available $\mathrm{N}, \mathrm{P}, \mathrm{K}$ content in open field soils was low because of the high rainfall as compared to poly house soils (Table 2). The higher available $\mathrm{N}$ content in soil under poly houses might be due to increased microbial population resulting faster decomposition of organic matter in summer season over the winter season. Among the different age groups, significantly higher available $\mathrm{N}$ was recorded in 3-5 years age group and the lowest was recorded in poly houses $>10$ years age group. Further, higher available $\mathrm{N}$ in soil was recorded in summer season over winter season (Table 2). The lower available $\mathrm{N}$ content in older age group of poly houses than younger age groups indicated the deterioration in organic carbon status, soil reaction and CEC of the soil was also 
reported by Singh (1991). In case of open field soils, lower available nitrogen content was recorded due to loss of nutrients through leaching in both winter and summer season.

Similarly, higher available $\mathrm{P}$ content was observed in summer season over winter season that might be due to release of $\mathrm{P}$ from fixed phosphate with increased in temperature (Sharma and Singh, 1999). Among the poly houses, 3-5 years age group poly houses showed higher available $\mathrm{P}$ over the other poly houses of other age groups (Table 2). Higher availability of $\mathrm{P}$ in surface soils over the subsurface soils attributed to the higher organic carbon content of the soils that convert the immobile P into labile P (Das and Ram, 2005).

Unlike available nitrogen and phosphorus, available potash in soil was higher during winter compared to summer season (Table 2). A decline trend of available potash content of higher age of poly houses over the open field soils was observed which might be due to consequent higher removal by crops (Bhardwaj and Omanwar, 1994). Further, the data revealed that potash availability in the soil was increased with the increasing depth, the lowest being in the surface layer which might be due to high clay content as reported by Dutta (1991).

Organic carbon content in the soil under field condition was more over the soil inside the poly during both winter and summer season indicating the higher temperature variation within and outside the poly houses (Fig.3.1 and 3.2). The declining trend of organic carbon in poly houses soil with the age of the poly houses was observed which might be due to faster decomposition of organic matter brought about by increased temperature $( \pm 3$ $5^{\circ} \mathrm{C}$ in summer and $\pm 5-7^{0} \mathrm{C}$ in winter) inside the poly houses leaving very less residual carbon in soils (Sen et al., 1984). Moreover, the less organic carbon content in summer season attributed to higher rate of decomposition because of high temperature, high population and activity of microbes during summer season also leads to faster decomposition of organic matter as compared to winter season. Higher organic carbon content of the surface $(0-15 \mathrm{~cm})$ soil over the sub surface $(15-30 \mathrm{~cm})$ was recorded which may be due to accumulation of different organic matter and efficient bacterial activity.

\section{Soil biological properties}

\section{Soil microbial population}

The congenial environment in open field soils had higher bacterial and fungal population and their activity over the poly house soils (Table 3). The population size of soil microorganism is directly related to soil organic matter content (Alexander, 1961). Further, the toxic substances produced during microbial activity or due to interaction might not be washed away in poly houses leading to lower microbial population compared to open field condition. The surface soils contained higher microbial population as compared to sub-surface soils during both winter and summer season which might be due to the better soil condition prevailed on upper layer in terms of nutrient status and organic matter content (Gupta and Tripathi,1988). Higher bacterial and fungal population during summer season as compared to winter season was also earlier reported by many workers (Helmeczi et al., 1984; Voinova-Raikova, 1984 and Das et al., 1991) and attributed to the application of fertilizers, decomposition rate of organic residue as well as favorable temperature in the soil.

\section{Enzyme activities}

The activity of dehydrogenase and phosphomonoesterase enzymes in soil 
increased significantly with increasing the age groups. The Dehydrogenase and phosphomonoesterase activity were highest in 0-2 years age group poly houses (Fig. 4.1, 4.2, 5.1 and 5.2). Flourescent di acetate (FDA) hydrolysis activity was recorded highest in open field soils as compared to poly house soils (Fig 6.1 and 6.2), which revealed the congenial natural environment for their activity and availability of sufficient organic matter in natural environment. This may be due to the fact that FDA hydrolysis activity was mainly affected by the stabilization degree of the added organic matter, and it was unaffected by the disturbance caused to soil micro flora despite the disturbance caused by the exogenous organic matter (Mondini et al., 2007).

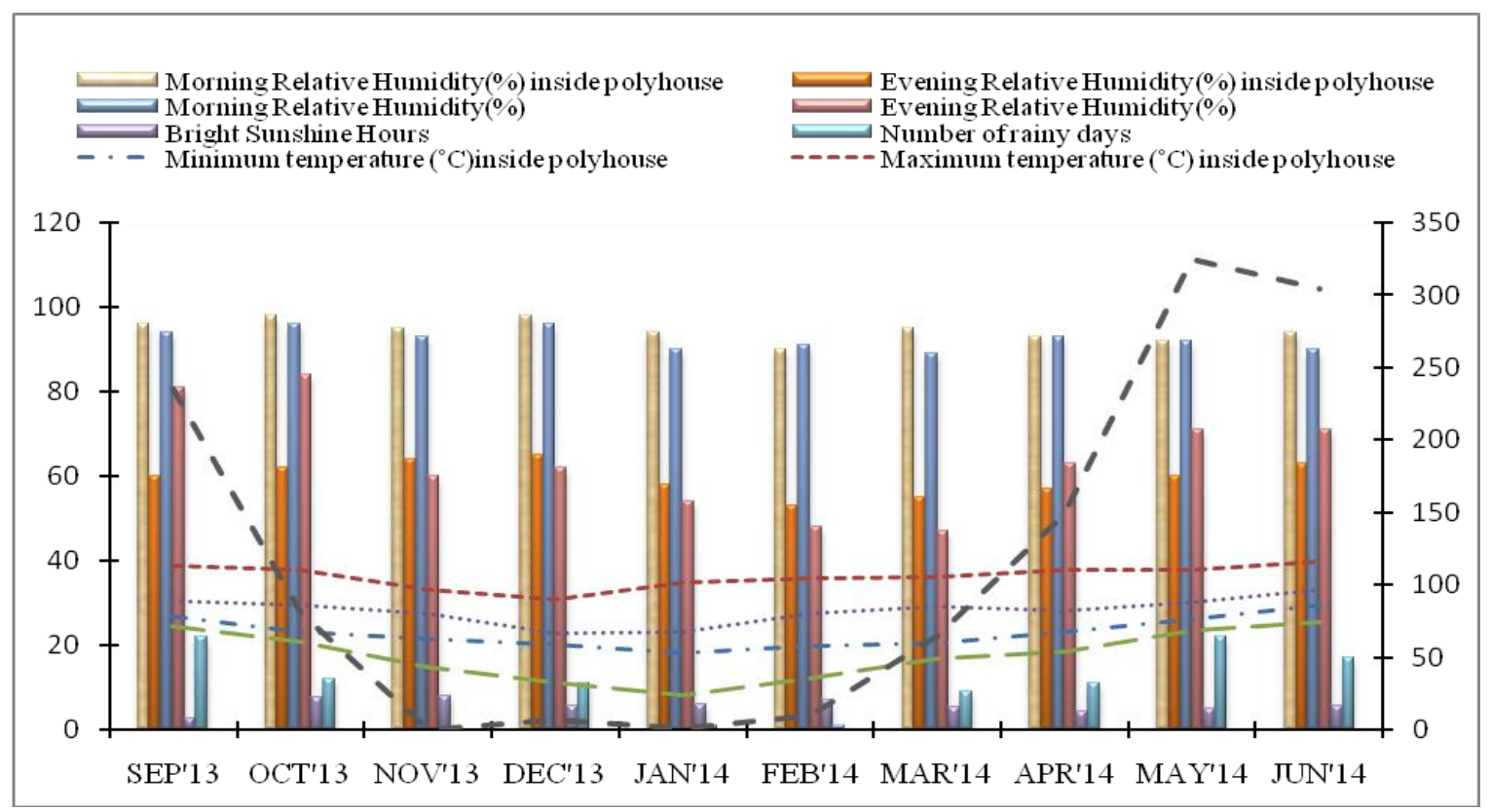

Fig.1 Maximum/minimum temperature and relative humidity inside and outside poly house, total rainfall, bright sunshine hour, number of rainy days during the study period

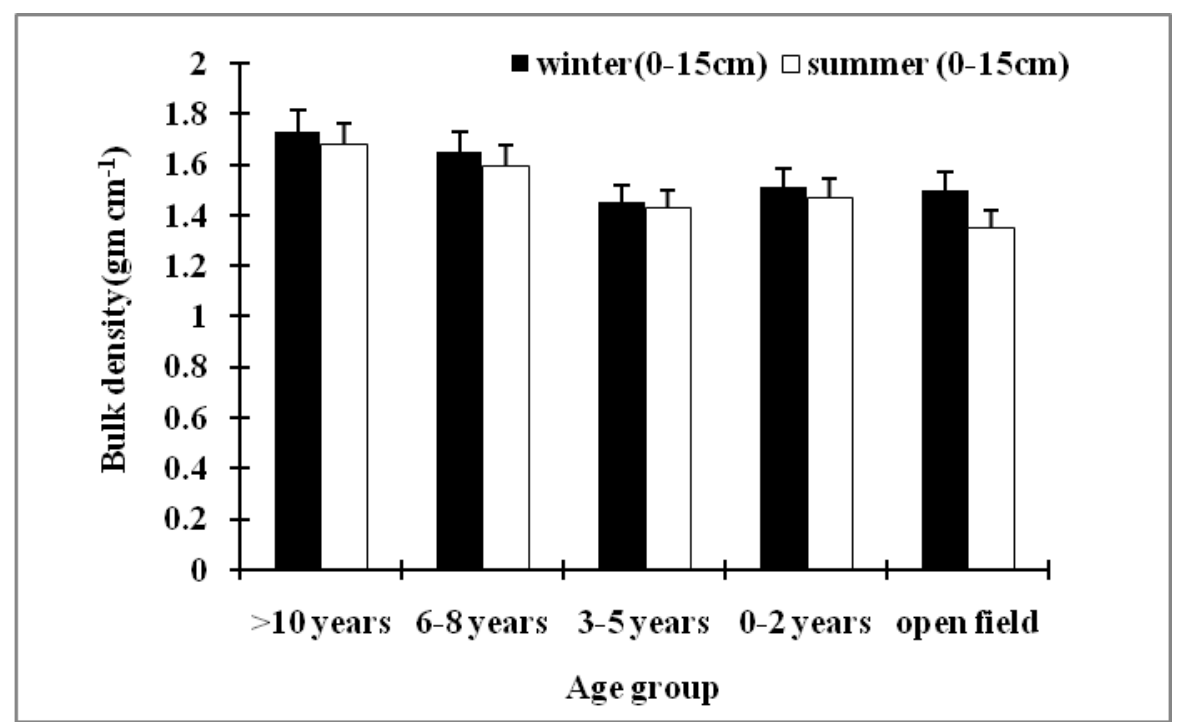

Fig.2.1 Effect of different age group of poly houses on soil bulk densities at $0-15 \mathrm{~cm}$ soil depth 


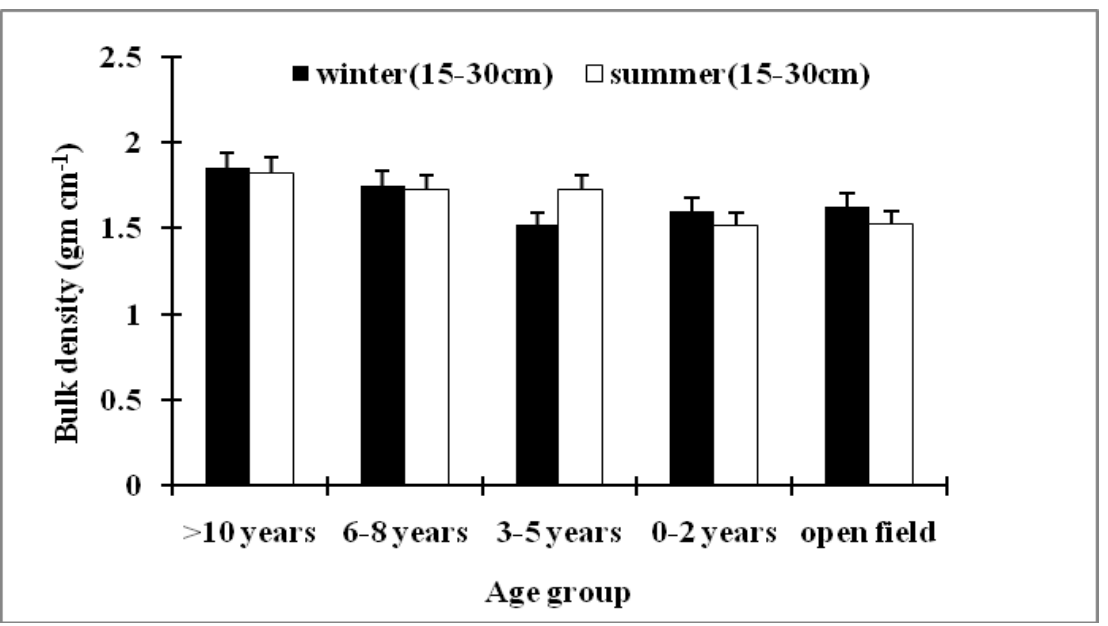

Fig.2.2 Effect of different age group of poly houses on soil bulk densities at $15-30 \mathrm{~cm}$ soil depth

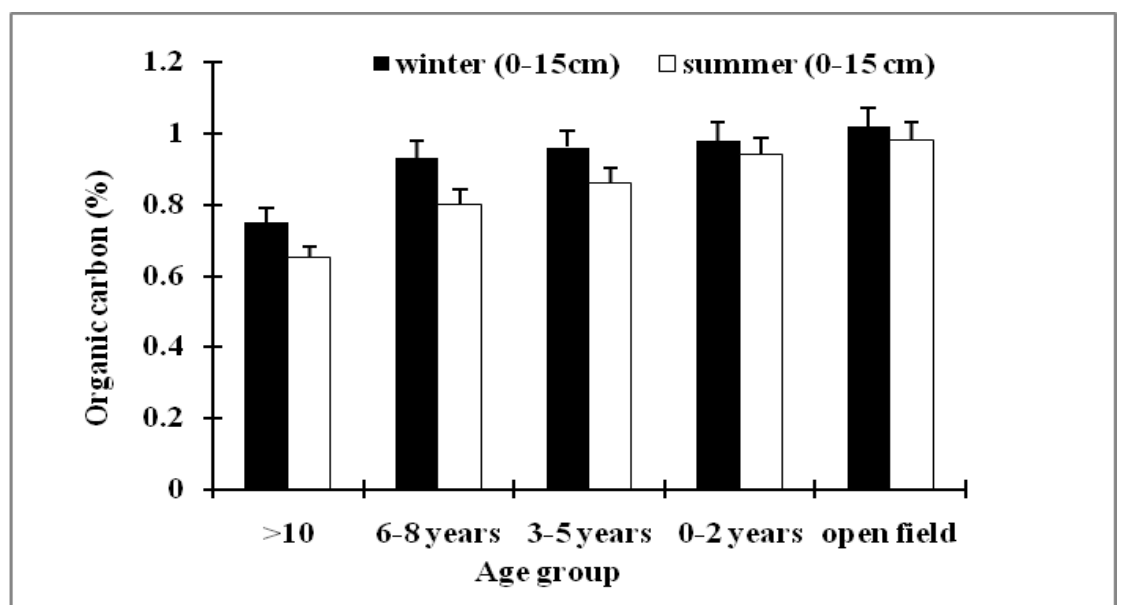

Fig.3.1 Effect of different age group of polyhouses on organic carbon content at $0-15 \mathrm{~cm}$ soil depth

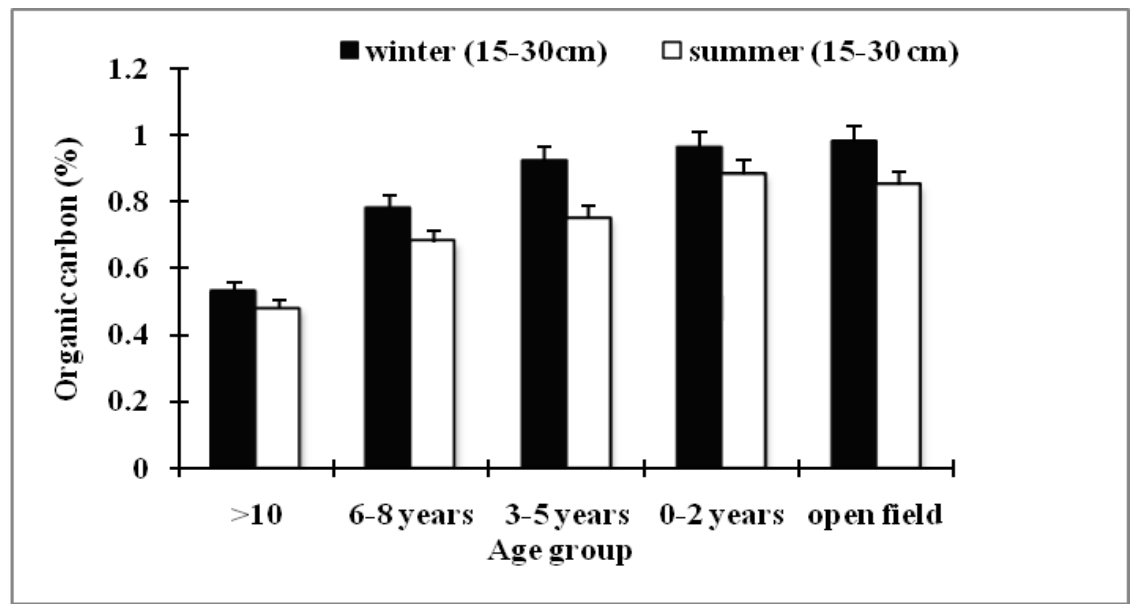

Fig 3.2 Effect of different age group of polyhouses on organic carbon content at $15-30 \mathrm{~cm}$ soil depths 


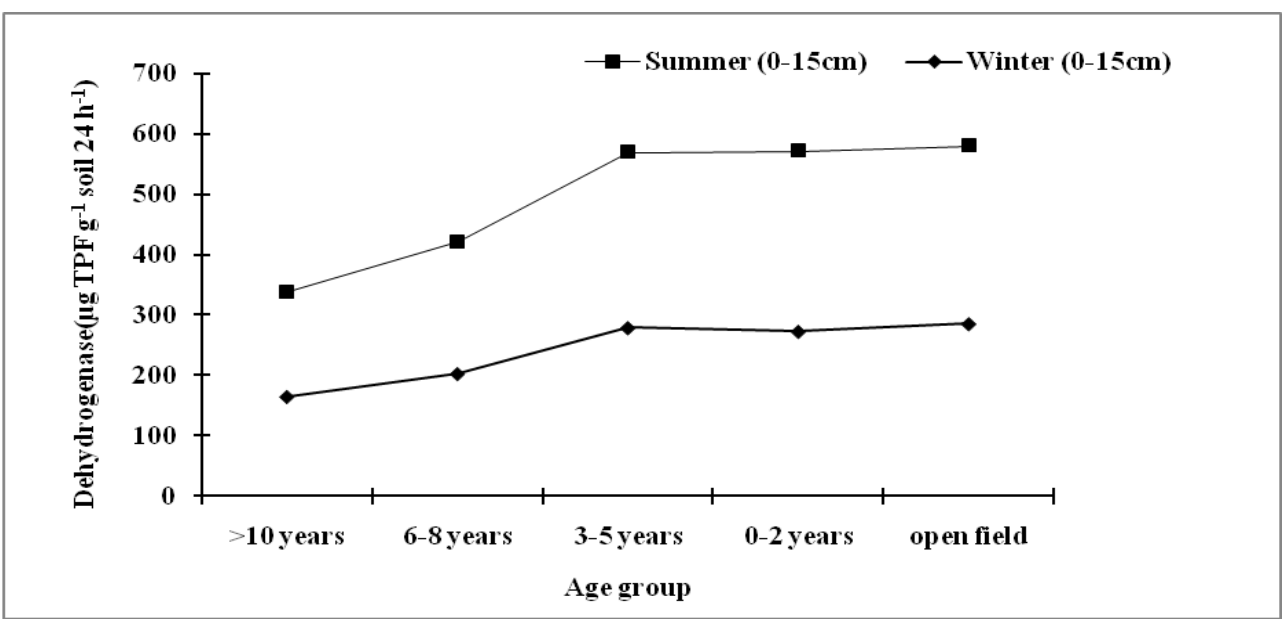

Fig.4.1 Effect of different age group of poly houses on dehydrogenase enzyme activity of soils at $0-15 \mathrm{~cm}$ depth

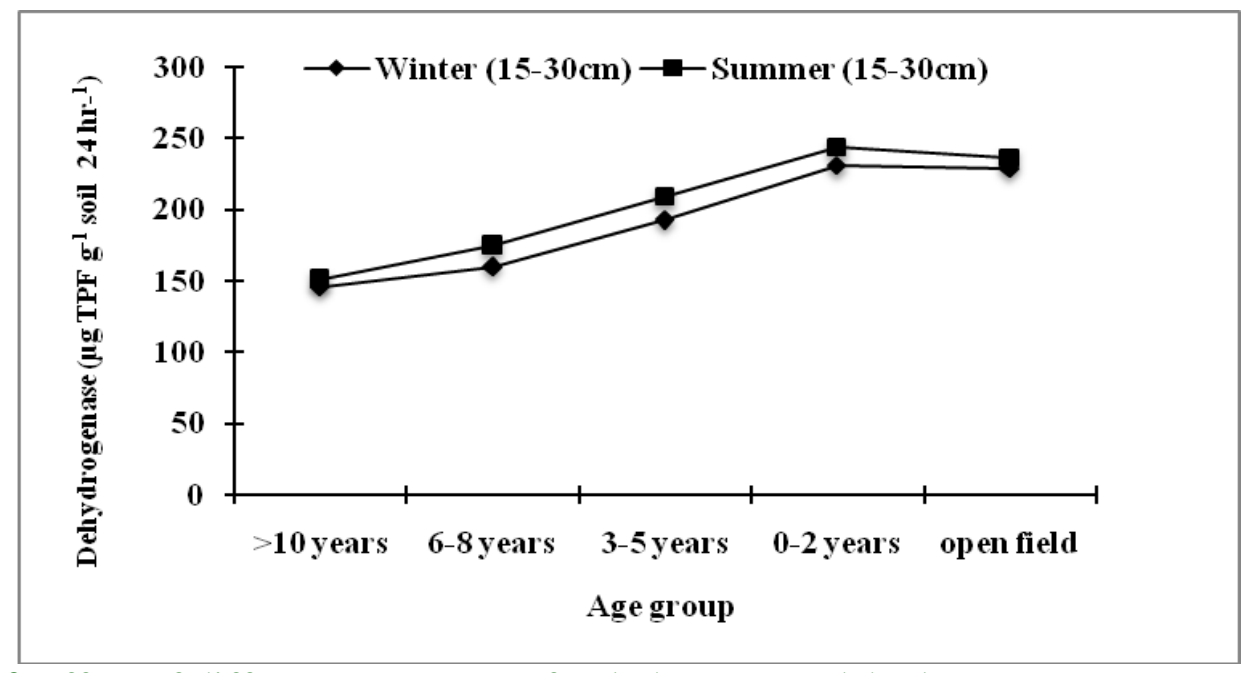

Fig.4.2 Effect of different age group of poly houses on dehydrogenase enzyme activity of soils at $15-30 \mathrm{~cm}$ depth

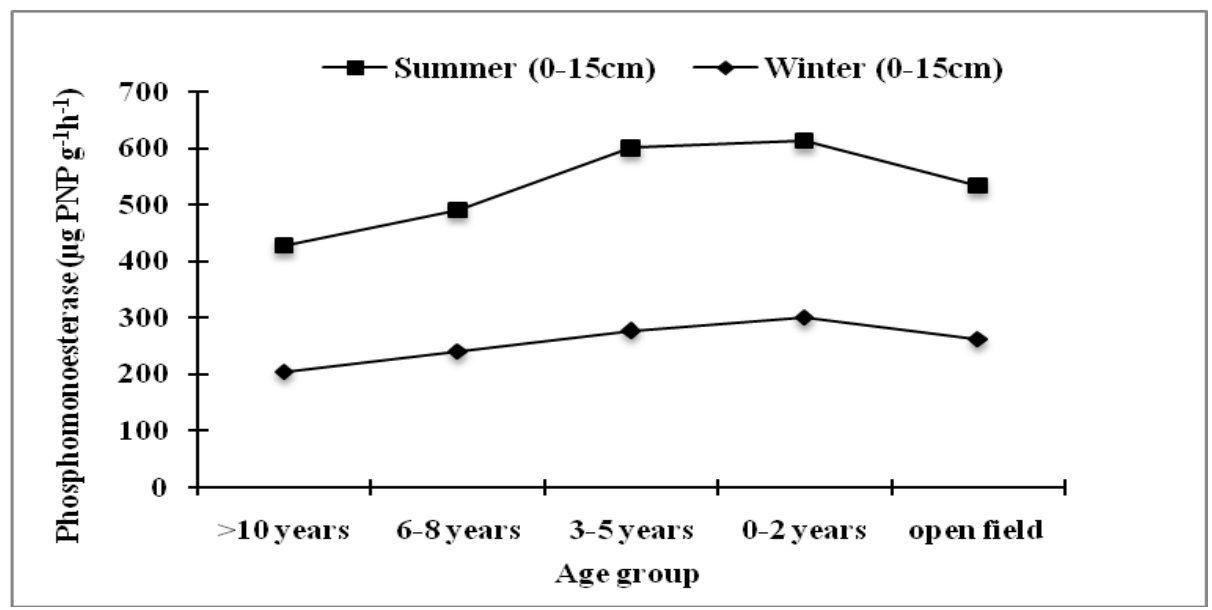

Fig.5.1 Effect of different age group of poly houses on phosphomonoesterase enzyme activity on soil at $0-15 \mathrm{~cm}$ depth 


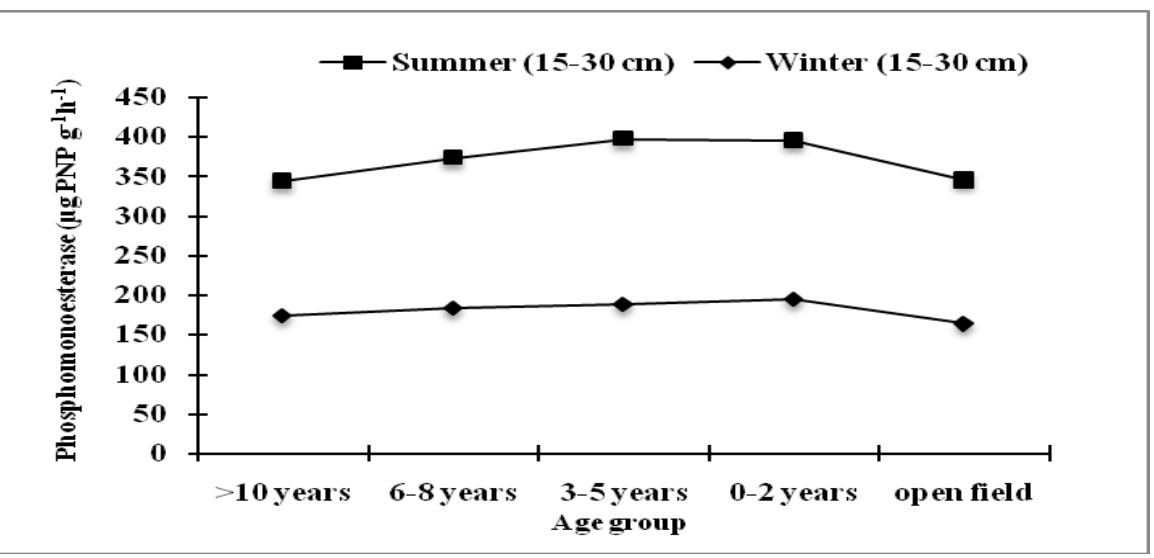

Fig.5.2 Effect of different age group of poly houses on phosphomonoesterase enzyme activity on soil at $15-30 \mathrm{~cm}$ depth

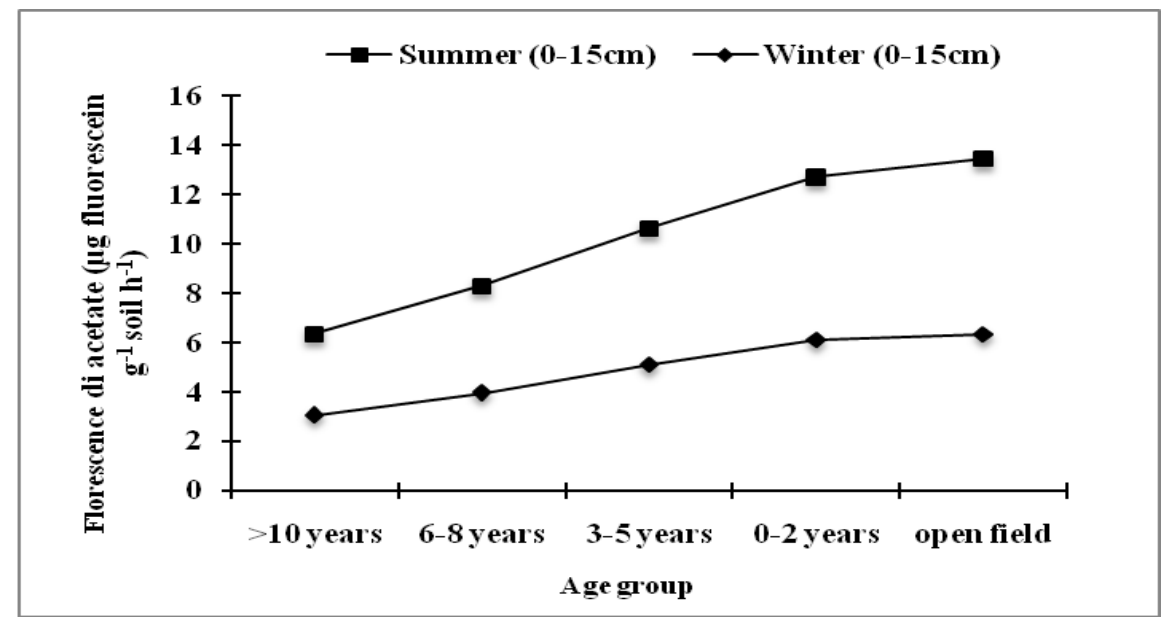

Fig.6.1 Effect of different age group of poly houses on FDA hydrolysis of soil at $0-15 \mathrm{~cm}$ depth

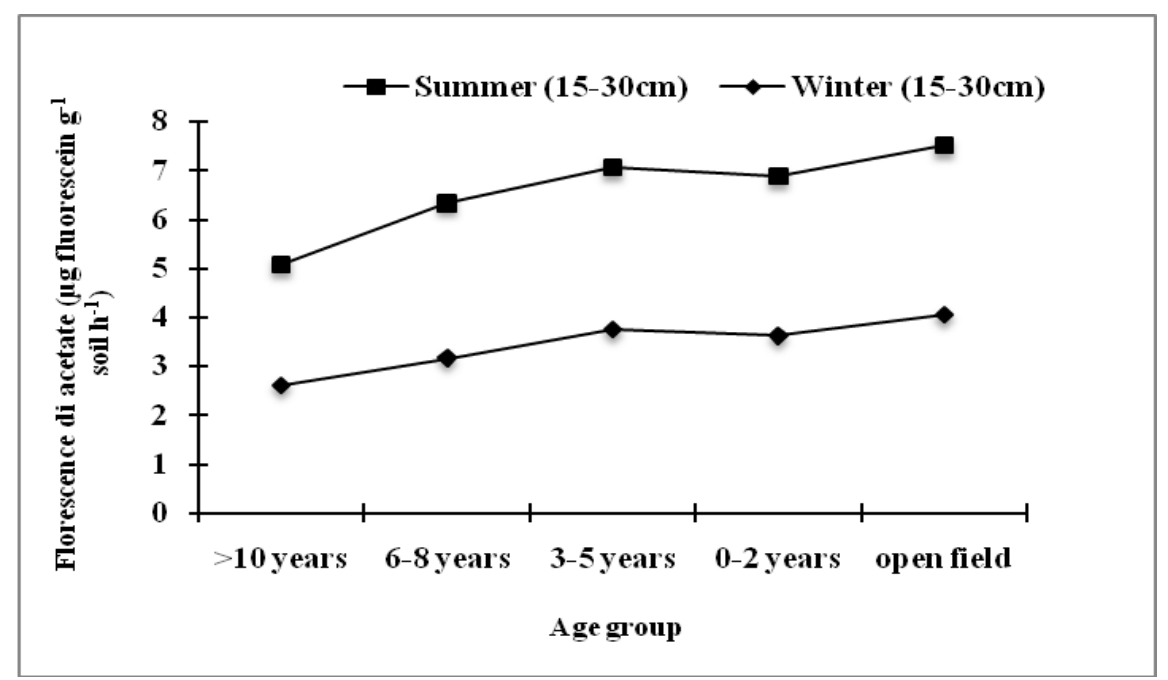

Fig.6.2 Effect of different age group of poly houses on FDA hydrolysis of soil at $15-30 \mathrm{~cm}$ depth 


\section{Microbial biomass carbon}

Higher microbial biomass carbon in open field soils compared to poly house soils might be due to the higher organic carbon content and microbial population in open soils than the poly house soils. The microbial biomass carbon was lowest in poly houses of above 10 years age group (Table 2) and might be due to the unfavourable environment for the microorganisms. The lesser degree of decomposition of organic matter due to low temperature and moisture revealed less microbial biomass carbon in winter season over the summer season.

Soils under poly houses required rejuvenation particularly after 6-8 years for improvement of physical, chemical and biological properties. Generally, poly house soil is subjected to higher temperature and less light intensity than natural soils for which organic matter, a key component of soil fertility, get decomposed fast in poly house and hence there is a reduction in level of this component. Proper maintenance of organic matter in poly house is therefore required so as to improve microbial activity and build up soil fertility. Appropriate management of nutrient, water, tillage as well as plant protection measures may be developed after 6-8 years of poly house cultivation for sustaining soil health and crop productivity.

\section{Acknowledgement}

The authors are thankful to the AICRP on Integrated Farming System and Department of Horticulture ,Assam Agricultural University, Jorhat-785013, for providing the necessary financial assistance and laboratory facilities to conduct the research.

\section{References}

Adam G. and Duncan H. (2001).Development of a sensitive and rapid method for the measurement of total microbial activity using fluorescent diacetate (FDA) in a range of soils. Soil Biology and Biochemistry, 33: 943-951.

Alexander, M. (1961).Introduction to soil microbiology, John Wiley and Sons, New York, pp. 21-27.

Antill, D.N. (1988). The use of low level plastics in horticultural field crops. Proceedings, Conference on 'Plastics in the Nineties'. 1988. British Agricultural and Horticultural Plastics Association.

Basumatary, A. (1995). Long term effect of integrated nutrient supply system on soil fertility. A Ph. D (Agriculture) thesis, submitted to Assam Agricultural University, Jorhat, Assam.

Bhardwaj, N. and Omar war, P.K. (1994) Long term effect of continuous rational cropping and fertilization on crop yield and soil properties. J Indian Soc. Soil Sci. 42: 387392.

Blake, G.R. and Hartge, K.H. (1986).Bulk Density.InKlute, A. (ed.) Methods of Soil Analysis. Part-I - Physical and Mineralogical Methods Second Edition. Am. Soc. Agron., Madison WI.

Casida, L.E.Jr. (1968). Methods for the isolation and estimation of activity of soil bacteria. The Ecology of Soil Bacteria (T.R.G.) Grev and D. Parkinson Eds) DD. 97-122. Livernool University Press.

Chandel, S. R. S. (2004). A Handbook of Agricultural Statistics, pp 281-287. Achal, Prakashan Mandir, Kanpur.

Chang, S.K. and Liao, F.S. (1989). Problems in the continuous cultivation of vegetables in plastic houses, Taiwan District Agricultural Improvement Station, R.O.C., on Taiwan

Das, D.K. and Ram, N. (2005).Effect of long term fertilization and manuring on soil health. Annals of Plant Soil Research, 7(1): 17-23.

Das, P.K., Nath, S. and Banerjee, S.K. (1991). Distribution of micro- organisms in soils under different forest cover at different altitude. Indian Agric. 35(4): 217-223

Dutta, S. (1991).Characterization and classification of soils of Instructional cum Research Farm of AAU, Jorhat. M.Sc. (Agri) Thesis, Assam Agricultural University, Jorhat. 
Gupta, R.D. and Tripathi, B.R. (1988).Microflora in some soil profiles of NorthWest Himalaya. J. Indian Soc. Soil Sci., 36(1): 75 -82 .

Helmeczi, B., Bessemyei, M., Katai, J. and Nagy, M. (1984). Combine effect of irrigation and fertilizers on some physiological group of soil bacteria. Soil Biol. Conserv. Biosphere, pp. 125-132.

Jackson, M.L. (1973). Soil chemical analysis.Prentice Hall of India Pvt. Ltd., New Delhi, India.

Lee, J.J., Park, R.D.; Kim, Y.W. ; Shim , J.H., Chae, D.H., Rim, Y.S. and Kyoon, B. (2004 ). Effect of food waste compost on microbial population, soil enzyme activity and lettuce growth .Biores.Technol. 93: 21 28

Li W, Lue.H.Y, Lui J.F (1996).The material and energy fluxes in greenhouse ecosystem and evaluation of its benefits. Ecolog Agric Res, 3:53-55.

Mondini, C., Cayuela, M.L., Roig, A., Contin, M. and Nobili, M. (2007).Floresceindiacetate hydrolysis, respiration and microbial biomass in freshly amended soils .Soil Biol.Biochem. 32: $543-612$.

Norman, P., Nilda, M.A., Pablo, Z. and Moria, B.V. (2000).Effect of clay minerals and organic matter on cation exchange capacity of silt fractions. J. Plant Nutr. Soil Sci., 163: 47-52.

Panse, V.G. and Sukhatme, P.V. (1967). Statistical Method for Agricultural Workers. $2^{\text {nd }}$ Edition, Indian Council of Agricultural Research, New Delhi, India.

Patil M.A. and Bhagat A.D.(2014). Yield response of cucumber (Cucumis sativus L.) to shading percentage of shade net. International Journal of Agricultural
Engineering, 7(1): 243-248.

Sen,P.K.;Mukherjee,M.and Debnath,N.C.(1984) Effect of temperature on organic carbon content in soils.J.Indian Society of Soil Science.47(2): 212.

Sharma ,B.M. and Singh, R.D. (1999) . Available Phosphate as affected by temperature. $J$. Indian Soc. Soil Sci. 47(3): 497 - 500.

Singh,K.P.(1991)Effect of continuous use of fertilizer, manures and lime on crop yields and fertility status in soil of Chota Nagpur,Bihar,New Agril.1(2):133-138.

Subbiah, B.V. and Asija , G.L. (1956). A rapid procedure for the determination of available nitrogen in soil. Current Science, 25: 256260

Tabatabai M. A. and Bremner J M. (1969).Use of p-nitrophenyl phosphate for assay of soil phosphatase activity. Soil Biology and Biochemistry, 1: 301-307.

Vance E. D., Brookes P C and Jenkinson, D. S. (1987). An extraction method for measuring soil microbial biomass C. Soil Biology and Biochemistry 19: 703-707.

Voinova - Rajkova, L.H. (1984). Change in microflora at different moisture content and soil temperature. Soil Biol.Conserv. Biosphere, 1: $77-83$.

Walkle,y A and Black I A. (1934). An examination of the Degtjareff method for determining soil organic matter and a proposed modification of chromic acid titration method. Soil Science, 37: 29 - 38.

Yaduvanshi, H.S., Tripathi, B.R. and Kanwar, B.S. (1985).Effect of continuous manuring on some soil properties of an alfisol. Journal of Indian Society of Soil Science,33: 700-703.

\section{How to cite this article:}

Kaberi Mahanta, R. Yendrembam, D. Nath, A. Baishya' M. C. Talukder, A. K. Sarma and D. J. Rajkhowa. 2020. Long Term Cultivation Effect on Soil Health Inside Poly Houses Under SubTropical Condition of North East India. Int.J.Curr.Microbiol.App.Sci. 9(03): 1648-1658. doi: https://doi.org/10.20546/ijcmas.2020.903.193 